\title{
A busca permanente pela compreensão do Jornalismo
}

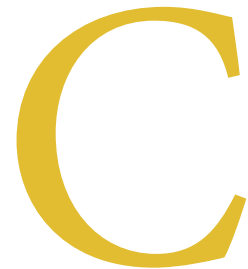

omo uma identidade social de um grupo, ethos etimologicamente vem do grego e descreve o conjunto de hábitos ou crenças que definem uma comunidade ou nação. No âmbito da sociologia e da antropologia, o ethos são os costumes e os traços comportamentais que distinguem um povo. São marcas de um grupo humano que o diferenciam de outros grupos sob os pontos de vista social e cultural. Em síntese, pode caracterizar valores característicos de uma cultura.

Se aceitarmos que as bases do Jornalismo Moderno foram estabelecidas no Século XIX, quando a imprensa se transforma em uma indústria de informação, podemos observar que se esboça ali uma identidade da cultura jornalística. O jornalismo é informação e não propaganda; o compromisso com a verdade factual; a vigilância, como um guardião da sociedade; a liberdade de expressão. Estes parecem ser valores incontestáveis historicamente atribuídos ao Jornalismo. Estes estariam ligados a papéis e, ao mesmo tempo, seriam garantias para sua credibilidade junto a esta sociedade.

Se o ethos representa os valores de uma cultura, temos que considerar que não há uma cultura, mas as culturas, como nos lembra Edgar Morin. A cultura de um grupo é influenciada por outras culturas, assim como esta influencia outras culturas. Não é imutável, está em permanente construção. Na cultura jornalística, o preceito de objetividade, por exemplo, tem experimentado outras interpretações ao longo do Século XX. Dessa forma, o fato é que a identidade do Jornalismo está também em permanente construção. Todas as transformações porque passa a humanidade, seja de caráter sociocultural, político, econômico, tecnológico dão novas faces às culturas. E podem promover também transformações na cultura jornalística, como às que temos historicamente observado e procurado compreender.

Por essas razões, entendemos que os esforços da academia através da pesquisa, em última análise, buscam a compreensão do ethos do Jornalismo e das relações que ele estabelece com a sociedade em diferentes épocas. Seja pelas reflexões teóricoepistemológicas, seja pelos estudos empíricos, as energias e o intelecto de seus pesquisadores se voltam para este fim maior. E nossa Revista Estudos em Jornalismo e Mídia participa desses esforços ao difundir os frutos dessa busca de compreensão.

Justamente o primeiro artigo desta edição, de Bárbara Maia Cerqueira, traz à discussão "As transformações no ethos do jornalista", tendo como foco a reformulação dos valores profissionais perante um cenário de convergência. Resultante de pesquisa de Mestrado, a análise mostra que alguns valores profissionais ainda estão presentes na prática jornalística, "enquanto outros desaparecem do discurso dos profissionais e novos valores surgem como balizadores nas redações". 
Permanências e transformações também estão tematizadas em "Dos relatos de Peucer a um ecossistema pós-industrial: elementos do jornalismo que transcendem barreiras temporais", de autoria de Janaína Kalsing. A pesquisadora defende que, passados mais de três séculos da difusão da tese De Relationibus Novellis (Os Relatos Jornalísticos), do alemão Tobias Peucer (1690), temas como a definição sobre o que é notícia, o papel dos jornalistas e questões mercadológicas continuam atuais no debate acerca do jornalismo.

A análise da produção de conteúdos editoriais dos jornais Nexo, do Brasil, e Vox, dos Estados Unidos para diferentes plataformas de redes sociais é o objetivo central do artigo seguinte, intitulado "Conteúdo multiplataforma de jornais nativos digitais em sites de redes sociais”, de Maíra Evangelista de Sousa e Gabriel Rizzo Hoewell. Combinando técnicas qualitativas e quantitativas, eles analisam postagens dos perfis dos dois veículos no Facebook, no Twitter, no YouTube e no Instagram, e percebem a permanente interação entre os dispositivos “jornal” e "plataforma de rede social" na conformação dos conteúdos editoriais.

A produção jornalística em um contexto de transformações tecnológicas e intenso uso das redes sociais digitais também é tematizada no quarto artigo desta edição: "O impacto da interatividade via WhatsApp na produção noticiosa do jornal Diário Gaúcho". Através de observação participante na redação deste periódico popular, Patrícia Pivoto Specht avalia a intervenção das audiências nas rotinas produtivas, em etapas como pauta, apuração e divulgação.

Os valores-notícia e os critérios de noticiabilidade que orientam o processo de seleção e produção noticiosa no campo do jornalismo são discutidos nesta edição da revista EJM em dois artigos. No primeiro deles, Marcos Paulo da Silva e Raquel de Souza Jeronymo partem de contribuições de duas correntes teóricometodológicas - a análise do enquadramento e a crítica retórica - para problematizar o conceito de "valor-notícia de construção". No segundo, Thays Assunção Reis estuda a noticiabilidade no jornalismo regional. Utilizando metodologia mista, a pesquisadora identifica e discute os critérios do que é noticiado na cobertura regional do Jornal O Progresso, diário do estado do Maranhão.

A relação do jornalismo com a subjetividade é outra das transformações que tem sido discutida em estudos da área. No artigo 'Viúvas do Veneno': a valorização da subjetividade como indício de rupturas paradigmáticas no jornalismo, Mayara Araújo e Edgard Patrício utilizam a Análise do Discurso Crítica para identificar e discutir, a partir do estudo de uma reportagem, como a subjetivação se revela no texto e nas práticas discursivas do jornalismo.

A subjetividade no jornalismo também é discutida no estudo realizado por Fabiana Moraes Silva, intitulado "Pode a subalterna outra subalterna calar? Limites e transbordamentos entre repórter e entrevistadas". Nele, Fabiana analisa textos jornalísticos sobre mulheres transgêneras e travestis e as ações e reações resultantes desses textos, discutindo, principalmente, "os fenômenos surgidos entre quem produz os textos (repórter negra, cisgênera) e o público analisado (mulheres transexuais e travestis brancas e negras)". A pesquisadora destaca o papel potente que pode ter a subjetividade para incluir as dissonâncias provenientes das interações que repensam práticas e representações.

O nono artigo desta edição, "A voz narrativa no livro-reportagem $O$ jornalista e o assassino, de Laísa Veroneze Bisol, analisa a articulação do narrador no jornalismo literário através do estudo deste livro, de autoria de Janet Malcolm. O 
estudo constata que o narrador utiliza uma linguagem próxima à oralidade e um tom de conselho aos leitores, além de se entrecruzar com a figura da autora.

Já o artigo "Crítica às práticas jornalísticas no livro de repórter: exemplo a partir da cobertura sobre a Palestina, de Tássia Becker Alexandre, Tatiane Milani e Beatriz Marocco, insere-se no âmbito dos estudos que consideram os chamados "livros de repórter" como espaço aberto "à interpretação crítica dos jornalistas e à construção de uma autoria individual". No trabalho, as autoras exploram o tema através de análise do livro de repórter Viagem à Palestina: Prisão a céu aberto, de Adriana Mabília.

O jornalismo especializado em esportes é o objeto de estudo de Antônio Sardinha, Elaide Martins da Cunha e Érica Favacho, no artigo em que analisam a cobertura realizada pela editoria de esportes dos dois principais jornais do Amapá: A Gazeta e Jornal do Dia. Apoiados na Análise de Conteúdo, nos estudos de noticiabilidade e nos de especialização jornalística, os pesquisadores constatam que a lógica de especialização adotada é temática e não de aprofundamento do conteúdo, e que a cobertura não reflete a diversidade das práticas esportivas locais por ainda reproduzir materiais jornalísticos de outros estados.

Bárbara Avrella e Cristiane Mafacioli Carvalho, por sua vez, assinam o $12^{\circ}$ artigo que a EJM publica nesta edição. Elas analisam o discurso do jornalista Ricardo Boechat no rádio (Jornal da BandNews FM) e na televisão (Jornal da Band), buscando identificar as estratégias utilizadas pelo apresentador para estabelecer contratos de comunicação com os públicos.

Fechando esta edição da revista, dois artigos exploram a relação entre o jornalismo e o entretenimento. Sílvio Anaz aborda "o sucesso do infotenimento" na crítica jornalística sobre produtos audiovisuais, a qual mobiliza formatos, linguagens e conteúdos que buscam seduzir a audiência. O autor discute a "eficiência comunicacional" do modelo de jornalismo de entretenimento ou infotenimento e analisa o impacto cognitivo dos principais recursos utilizados por esses produtos.

Já a pesquisadora Clara Bezerril Câmara reflete acerca do papel do entretenimento nas narrativas jornalísticas sobre a política. Ela apoia-se em estudos sobre a relação da política com a cultura popular e do jornalismo com a narrativa, para desenvolver o argumento segundo o qual a observação do caráter narrativo das notícias pode iluminar análises de um contexto jornalístico onde são cada vez menos aparentes as fronteiras entre entretenimento e informação.

Na seção Entrevista, o professor de Ética em Barcelona, Carlos Miguel Ruiz Caballero, é entrevistado por Laerte José Cerqueira, integrante do Grupo de Pesquisa Jornalismo e Contemporaneidade da Universidade Federal de Pernambuco. Na entrevista, Carlos Caballero enfatiza que um dos desafios da ética jornalística na atualidade está no uso das imagens. Ele também manifesta preocupação em relação ao poder simbólico do cidadão no acesso às tecnologias de comunicação e informação.

A edição é encerrada com a resenha "O ponto de partida para uma teoria das narrativas jornalísticas”, de autoria de Magali Moser, sobre o livro "Narrativas midiáticas contemporâneas: perspectivas epistemológicas”, organizado por Demétrio de Azeredo Soster e Fabiana Quatrin Piccinin (2017).

Por fim, agradecemos a grande colaboração e atenção da equipe de avaliadores e de revisores desta edição.

Boa leitura!

Jorge Kanehide Ijuim

Terezinha Silva 